\title{
LECTURERS' ICT COMPETENCY NEEDS IN THE USE OF PERIPHERAL EQUIPMENT FOR TEACHING IN POLYTECHNICS IN NORTH- EAST ZONE OF NIGERIA
}

\author{
Dr. M. U. Michika \\ College of Engineering Technology \\ Adamawa State Polytechnic, Yola, Nigeria \\ Dr. S. S. Manabete \\ Department of Science and Technology Education \\ University of Jos, Nigeria \\ Correspondence: mumichika82@gmail.com,mmichika@yahoo.com \\ manabete2002@gmail.com \\ DOI: $10.31364 / S C I R J / v 7 . i 2.2019 . P 0219611$ \\ http://dx.doi.org/10.31364/SCIRJ/v7.i2.2019.P0219611
}

\begin{abstract}
The study examinedthe ICT competency needs of lecturers in the use of peripheralequipment for teaching in polytechnics in North-East Zone of Nigeria. One purpose was identified and studied. To guide the study, one research question was formulated and answered. In like manner, one hypothesis was tested. A structured questionnaire, designed by the researchers, was used to collect data from a sample of 324 respondents, drawn from three colleges, i.e. College of Science and Technology, College of Engineering Technology and College of Administrative and Business Studies. Mean and standard deviation were used to answer the research question while the analysis of variance statistic was used to test the hypothesis at 0.05 level of significance. Findings revealed that lecturers teaching in polytechnics in the North-East Zone required the following ICT peripheral equipment competencies such as use of the digital camera, use of the web camera for internet communication, use of the scanner to copy messages, setting up and using Liquid Crystal Displays (LCDs) and use of a multimedia projector. The study also found that a significant difference existed in the mean scores of the responses of the three groups of respondents regarding ICT competency needs in the use of peripheral equipment. A Scheffe posthoc multiple comparison test however, revealed that lecturers in the three Collegeswere responsible for bringing about the significant difference in the mean scores of their responses. The study recommended among other things, that Government should increase funding for ICT with a view to upgrading existing ICT facilities and supplying new ones, and the international community, especially donor agencies needs to provide ICT assistance to polytechnics in the North-East, most especially in the area of ICT training and facilities supply.
\end{abstract}

Key words: Competency, ICT, Peripheral, Equipment

\section{INTRODUCTION}

In today's world, the term information and communication technology (ICT) has taken over developments in the political, economic, social, and educational needs of a nation. The term simply means the use of computer and telecommunications based equipment for storage, processing and dissemination of information. It is the systematic application of computers and other technologies to acquire, organize, process, store, retrieve and disseminate information to bring about effective exchange of information in communication (Andural\&Ikyumen, 2006; Ojowu\&Agbo (2006)". Used in the classroom for instructional purposes, ICT has been viewed as e-learning which is an electronic mode of knowledge sharing and transmission, which in most cases, does not necessarily involve physical contact between the teacher and the learner (Mac-Ikemenjima, 2005), In the view of Asabere and Ahmed (2013), e-learning usually involves the use of desk top computers for teaching and learning in sites or at a distance. In this study, e-learning is taken to mean the use of ICT facilities for the purpose of teaching and research in polytechnics in Nigeria in general and the North-East in particular. 
Polytechnic are tertiary institutions vested with the responsibility of training technical middle level manpower with relevant skills in various disciplines for middle level employment. Such institutions offer various technological and business programmes leading to the award of National Diploma and Higher National Diploma certificates. They are also institutions vested with the responsibility of providing part-time and full-time courses in engineering, technology, applied science, business and management leading to the production of trained manpower who are self-reliant and enterprising (Yakubu (2002; FRN, 2013),

There are serious challenges confronting polytechnics in their effort to train manpower for useful ICT skills acquisition and this has been addressed in literature by various authors. For example, Anderson(1997), Earle (2002), Kozma, McGhee, Quellmalz and Zalles (2004) and Ezeoba and Okafor (2015), identified infrastructural deficiencies, globalization, quality of personnel to implement e-learning in the polytechnics as some of the challenges. Others are lack of incentives, lack of reliable access to electricity,geographical factors, resistance to change, lack of time allotted to ICT training and use and technical faults with the ICT facilities. These challenges have to a large extent, impacted on the competence of lecturers in the polytechnics to use ICT for instructional purposes, as the lecturers are viewed as the key role players in planning and developing effective e-learning courses (Mayisela, 2014). There is therefore a consensus among ICT educators that teachers teaching in the polytechnics lack the competence and confidence to use ICT in education (Kumar \& Kumar, 2003; Yusuf, 2005; Amassoma, Ayanda and Tijjani (2010). There is therefore, the urgent need for the teachers to undergo an intensive programme of ICT training, especially as regards peripheral equipment and then supporting them in the ownership of their own personal computers. This will undoubtedly make them effective in their work (Bennett, 2002; Kumar \& Kumar (2003; ICT in Education, 2004; Asabere\& Ahmed (2013). The inability of teachers in polytechnics to integrate ICT in teaching and learning is traced to their lack of possession of the necessary skills and competencies. This development has contributed immensely to the need for this study.

\section{Purpose of the Study}

Determine the ICT competency needs of lecturers in the use of peripheral equipment for teaching in polytechnicsin North-East Zone of Nigeria?

\section{Research Questions}

What are the ICT competency needs of by lecturers in the use of peripheral equipment for teaching in polytechnics in North-East Zone of Nigeria?

\section{Test of Hypotheses}

Ho: There is no significant differences in the mean responses of lecturers of College of Engineering Technology, College of Science and Technology and College of

Administrative and Business Studies on the ICT competency needs of lecturers in the use of peripheral equipment for teaching in polytechnicsin North-East Zone of Nigeria

\section{LITERATURE REVIEW}

According to Andural and Ikyumen, 2006:55), ICT refers to "the systematic application of computers and other technologies to acquire, organize, process, store, retrieve and disseminate information to bring about effective exchange of information in communication". Its facilities and components are many and varied. They include photocopiers, duplicating machines, the satellite, television, radio telephony, scanners, and computers (Dahiru, 2005). Andural and Ikyumen added that ICT includes computer hardware, specialized application and software packages, peripherals, data bases and data banks. ICT also includes the electronic mail (email) and the world wide world (WWW) (Ater, Tiough\&Nevka, 2006). The author added that computer softwares also include diskettes, video disks and CD ROM, stressing that ICT facilities link learners to information sources, help them to visualize problems and solutions and track learner progress. Andural, Abodo and Ikyumen (2006) added 
that ICT facilities also include video cameras, microphones, fax machines, audio and video recorders and players and electric type writers. The facilities also increase teacher productivity.

ICT has occupied a prominent place in the Millennium Development Goals strategy one of whose educational goal is the achievement of universal primary education (Issa, n.d.). Issa held that the MDG Summits recommended the provision and improvement of ICT connectivity for all schools, universities, health institutions, libraries, post offices, among others. The indicative targets of this goal was to, among others, connect villages with ICTs and establish community access points, connect universities, colleges, secondary schools and primary schools with ICTS, and connect scientific and research centres with ICTs.

There are various ways that ICT can be used in e-learning. According to Peraton and Creed (2009), since the 1920s and 1950s, the radio and the television have been used widely in direct class teaching, school broadcast and general educational programmes. Peraton and Creed explained that direct class teaching uses what is known as Interactive Radio Instruction in which the approach presents ready-made direct teaching of about 20-30 minutes. In school broad cast, printed materials, and cassettes, and CD-Roms are utilized. In general education programme utilization, Peraton and Creed said the approach involves radio and TV educative programmes meant for community enlightenment. It involves new programmes, documentaries, shows, cartons and quizzes.

In order to function effectively in the classroom in this information age, teachers are required to possess vital competencies to operate ICT software and hardware. In view of this, though Marija and Palmira (2007) classified ICT competencies into two broad areas, namely, basic and educational ICT competencies, Kirschner and Woperies in Yusuf and Balogun (2011:20) highlighted the following major ICT teacher competencies: competency in making personal use of ICT, mastery of a range of educational paradigms that make use of ICT, competency in making use of ICT as mindstool, competency in making use of ICT as tool for teaching, competency in mastering a range of assessment paradigms which involve use of ICT; and competency in understanding the policy dimensions of the use of ICT for teaching and learning. Because of the crucial nature of the need for teachers to possess competencies to use ICT in the classroom, the United Nations Educational Scientific and Cultural Organization (UNESCO, 2008a, 2008b) formulated standards for teachers in six broad areas, namely, policy formulation, curriculum and assessment, pedagogy, the use of technology, school organization and administration, and teacher professional development. The standards are intended to improve teachers' skill and competency in the use of ICT in an innovative way for teaching, collaboration with colleagues and for school organization.

In this information age, it is required of teachers to employ ICT facilities in their teaching. In other words, teachers are required to have skills and competencies in basic computer operations such as running a word, connection of a computer and its peripherals and moving files between drives. They also need to have competencies in the use of application software such as entering a new file in Microsoft word, filtering files, updating data in database, competency in using ICT as tool for teaching and competency in mastering a range of assessment paradigms which using the ICT (Kirschner\&Woperies, 2003). However, Lelitiren, (1997) explained that many pre-service teachers have not been equipped with basic computer skills. Yusuf (2005) added that quite a substantial number of teachers are not competent in basic computer operation and in the use of generic software.

The term "Competency" in the opinion of Eraut (1998), means a system of complex actions including the knowledge, abilities and attitudes required for the successful completion of tasks. The Common Wealth Department of Education, Science and Training (2002) defined competence as the ability to combine and apply relevant attributes such as skills, sensitivities, and high levels of knowledge to particular tasks in particular contexts. Espasa, Guash and Alvarez (2009) added that external social demands, capabilities, individual disposition and context are all part of the complex nature of competencies. The term "skill", according to Amankwah (2011), refers to a task or group of tasks performed to specific level of competency or proficiency through the use of an instrument or equipment. In this work, the term "competence" refers to the skill or ability an individual possesses to combine and apply relevant behavior characteristics to particular tasks for the achievement of the goals of instruction. 
The Department of Public Instruction (2002) outlined eight basic competencies needed by serving and pre-service teachers. These competencies are: 1) Computer operation skills; 2) Set-up skills; 3) Maintenance and trouble shooting skills; 4) Word processing/introductory desktop publishing; 5) Spreadsheet/graphics; 6) Database; 7) Networking; and 8) Telecommunications/media communication (including images and audio processing), multimedia integration. The Department of Public Instructionalso outlined five advanced competencies which outlined, namely, 1) Curriculum; 2) Subject specific knowledge; 3) Design and management of learning environment resources; 4) Child development, leaning and diversity; and 5) Social, legal and ethical issues. Idialo (2007) further buttressed that teachers teaching in tertiary institutions need to possess ICT competencies such as operating computers and use basic software for word processing, spreadsheets, e-mail, etc, evaluating and using computers and related ICT tools for instruction, evaluate Educational software such as CAD/CAM, arch cad, Corel draw multism and multiband electrical and electronic work bench, and other specific software fitted to their areas of specialization, and creating multimedia documents to support instruction, All of these, as argued by Adeyanji (2008) and Tinio (2008), will assist teachers to serve as facilitators of students' learning and mediators between learners andwhat they need to learn.

It is difficult to have a useful interaction between teachers and students as regards the use of ICT without the enabling environment. According to UNESCO (2002), to create this enabling environment, students and teachers need to have sufficient access to digital technologies and internet facilities in their schools. Such digital facilities must be available and be of high quality, meaningful and culturally responsive to this digital age. Consequently, according to Chinda (2013) e-learning bridges the gap among institutions which involve no physical facilities but which are facilitated by computer hardware and software. This arrangement enables also learners to to interact with each other in the absence of an instructor. Wuru (2008) held that e-learning involves passing instructional materials from a repository to learners, teachers and researchers, distant and near. Teaching and learning activities are easily carried out on the internet through the world wide web (www).Submitting a report to the World Bank, Twinumogisha (2005) stressed the need for tertiary institutions to have their teachers acquire ICT competencies among others, in peripheral devices which include high speed network printers, scanners and external DVD writers.

Jegede (2009) conducted a study on “Assessment of Nigerian teacher educators' ICT training”. The study used a descriptive survey design. It collected data from 469 teacher's educators using the questionnaire. The questionnaire required information on ICT training background, competence and use level of teacher educators. Descriptive statistics of mean and standard deviation were used to analyze data relating to the research questions. One-way ANOVA and Chi Square were used to test the hypotheses at 0.05 level of significance. The analysis of the results revealed that more than half of the educators had been exposed to one form of ICT training or the other. However, the pre-service training received excluded the use of ICT in instruction. The study also found that training delivery did not have any varying effect on basic ICT skills.

Miller (1997) conducted a study which determined the level of usage of 18 selected computer resources by technical teachers. The population of the study was 282 vocational technical educators selected from six different vocational disciplines, namely Home Economics Education, Agricultural Education, Industrial Education, Business Education, Marking Education and Health Occupation Education. The instrument for data collection included a Resource Usage Scale. Respondents were required to rate how often they used each computer related resource. A 4-point scale was used to rate items in the questionnaire, covering the following ICT competency areas, namely, productivity software (word processing, spread sheet, data base management), graphic application (graphics presentation, desktop publishing software), interactive technologies (authority software, multimedia and CD-ROM), telecommunication resources (Internet, electronic mail, commercial on-line services, etc), and Computer Assisted Instruction (Simulation and games, drilling and practice, tutorials, etc). Mean and standard deviation were used to answer the research questions. Multivariate and Univariate Analysis of Variance tested the hypotheses Findings revealed that Business Education Teachers, while utilizing familiar types of computer resources at high levels, were not incorporating the newer technologies in their instruction. The study also found that there were no significant differences within groups in total and categorical use of computers. 


\section{METHODOLOGY}

It was found suitable to employ descriptive survey research design for the study where a seven-item structured questionnaire, developed by the researchers, was used to collect data from a randomly drawn sample of 324 lecturers from the nine polytechnics in the North-East Zone of Nigeria, namely, Federal Polytechnic, Mubi, Adamawa State Polytechnic, Yola, Federal Polytechnic, Bauchi, AbubakarTatari Ali Polytechnic, Bauchi, Ramat Polytechnic, Maiduguri, Federal Polytechnic, Bali, Taraba State Polytechnic, Jalingo, Federal Polytechnic, Damaturu, and Yobe State Polytechnic, Geidam. The sample of 324 lecturers consisted of 111 from the College of Science and Technology (CST), 95 from the College of Engineering Technology (CET) and 118 from the College of Administrative and Business Studies (CABS).

The seven-item questionnaire dealt with the ICT competency needs of lecturers in the use of peripheral equipment for teaching in polytechnics in North-East Zone of Nigeria. The questionnaire was validated by relevant experts after which it was trial tested on 30 respondents outside the study area, that is lecturers from Plateau State Polytechnic BarkinLadi and Kaduna Polytechnic, Kaduna, to establish the internal consistency of the instrument. Cronbach Alpha was used to the determine of the reliability coefficient of the instrument. The Alpha value of 0.81 was obtained for the whole instrument and this was considered sufficient carrying out the study.

The items in the questionnaire were treated on a five-point Likert type scale. Respondents were required to tick the option which best described their views on the items. Section A was rated on the five-point Likert type scale as follows:

The sections were rated on the five-point Likert type scale as follows:

Highly Needed (HN)

Needed (N)

Moderately Needed (MN)

Less Needed (LN)

Least Needed (LeN)
5 points

$$
\text { - } 4 \text { points }
$$

3 points

- $\quad 2$ points

- 1 point

Table 1 presents the table of true limits of real numbers.

Table 1: Table of True Limits of Real Numbers

\begin{tabular}{ll}
\hline Designation & Limits \\
\hline Highly Needed (HN) & $4.50-5.00$ \\
Needed (N) & $3.50-4.49$ \\
Moderately Needed (MN) & $2.50-3.49$ \\
Less Needed (LN) & $1.50-2.49$ \\
Least Needed (LeN) & $0.50-1.49$ \\
\hline
\end{tabular}

Mean and standard deviation were used to answer the research questions while the analysis of variance (F-test) was used to test the hypothesis at 0.05 level of significance. From Table 1, to effect decision, a mean score of 3.50 and above was accepted as "Needed". Mean scores which ranged between 2.50 and 3.49 were considered "Moderately Needed". In like manner, mean scores less than 2.50 were taken as "Least Needed". To take decision with the F-test, where F calculated (F-cal) was less than F critical (F-crit), the hypothesis was upheld. The hypothesis was rejected where F-cal exceeded F-crit (Uzoagulu, 2011).

\section{RESULTS AND DISCUSSION}

Data collected were presented in tables based on the research questions and hypotheses.

\section{Research Question}

What are the ICT competency needs of lecturers in the use of peripheral equipment for teaching in polytechnics in North-East Zone of Nigeria? 
Data presented in Table 2 were used to answer this research question

Table 2: Mean Ratings and Standard Deviation of the Responses of the Respondents in CST, CET and CABS on the ICT Competency Needs of the Respondents in Perceived Important in the use of Peripheral Equipment for Teaching in

\section{Polytechnics}

\begin{tabular}{|c|c|c|c|c|c|c|c|c|c|}
\hline \multirow[b]{2}{*}{$\mathbf{S} / \mathbf{N}$} & \multirow[t]{2}{*}{ Items } & \multicolumn{2}{|c|}{$\begin{array}{c}\text { CST } \\
\mathrm{n}_{1}=111\end{array}$} & \multicolumn{2}{|c|}{$\begin{array}{c}\text { CET } \\
\mathrm{n}_{2}=95\end{array}$} & \multicolumn{2}{|c|}{$\begin{array}{c}\text { CABS } \\
\mathrm{n}_{3}=118\end{array}$} & \multirow{2}{*}{$\begin{array}{c}\text { Grou } \\
\mathrm{p} \\
\text { Mean } \\
\overline{\mathrm{X}}_{\mathrm{G}}\end{array}$} & \multirow[t]{2}{*}{ Remarks } \\
\hline & & $\overline{\mathbf{x}}_{1}$ & $\mathrm{~b}_{1}$ & $\bar{x}_{2}$ & $\mathrm{~b}_{2}$ & $\bar{x}_{3}$ & $5_{3}$ & & \\
\hline 1 & Using a digital camera & 4.17 & 0.85 & 3.90 & 1.02 & 3.97 & 0.85 & 4.02 & $\mathrm{~N}$ \\
\hline 2 & $\begin{array}{l}\text { Using the web camera to } \\
\text { communicate on the internet }\end{array}$ & 4.13 & 0.84 & 3.77 & 1.06 & 3.89 & 0.90 & 3.94 & $\mathrm{~N}$ \\
\hline 3 & $\begin{array}{l}\text { Using the scanner to copy } \\
\text { images }\end{array}$ & 4.17 & 0.84 & 3.92 & 0.95 & 3.96 & 0.85 & 4.02 & $\mathrm{~N}$ \\
\hline 4 & $\begin{array}{l}\text { Setting up a Liquid Crystal } \\
\text { Display (LCD) }\end{array}$ & 3.81 & 0.89 & 3.51 & 1.10 & 3.68 & 0.98 & 3.67 & $\mathrm{~N}$ \\
\hline 5 & Using a Liquid Crystal Display & 3.77 & 0.94 & 3.49 & 1.10 & 3.63 & 1.02 & 3.64 & $\mathrm{~N}$ \\
\hline 6 & $\begin{array}{l}\text { Setting up a multimedia } \\
\text { projector(speaker) }\end{array}$ & 3.97 & 1.12 & 3.89 & 1.04 & 3.94 & 0.96 & 3.94 & $\mathrm{~N}$ \\
\hline 7 & $\begin{array}{l}\text { Using a multimedia projector } \\
\text { (e,g, power point presentation) }\end{array}$ & 4.08 & 1.07 & 3.96 & 1.03 & 3.97 & 0.96 & 4.00 & $\mathrm{~N}$ \\
\hline
\end{tabular}

Key

$\begin{array}{lll}\mathrm{n}_{1} & - & \begin{array}{l}\text { No. of lecturers of CST } \\ \mathrm{n}_{2}\end{array} \\ \mathrm{n}_{3} & - & \text { No. of lecturers for CET } \\ \overline{\mathbf{X}}_{1} & - & \text { No. of lecturers of CABS } \\ \overline{\mathbf{X}}_{2} & - & \text { Mean score of lecturers of CST } \\ \overline{\mathbf{X}}_{3} & - & \text { Mean score of lecturers of CET } \\ \overline{\mathrm{X}}_{\mathrm{G}} & - & \text { Grand mean } \\ \mathrm{HN} & - & \text { Highly Needed } \\ \mathrm{N} & - & \text { Needed } \\ \mathrm{MN} & - & \text { Moderately Needed } \\ \mathrm{LN} & - & \text { Less Needed } \\ \text { LeN } & - & \text { Least Needed }\end{array}$

The data collected to provide answer to this research question are presented in Table 2 . The mean ratings of the table ranged between 3.64 and 4.02. The standard deviation of the mean rating of the responses of the respondents ranged between 0.84 and 1.12. This shows that the respondents' views do not differ significantly from each other. All the 7 items in the table have been rated needed by respondents. The items are 1, 2, 3,4,5,6 and 7. The overall grand mean of the table is 3.89. This result shows that lecturers in College of Engineering Technology, College of Science and Technology and College of Administrative and Business Studies needed ICT competency in the use of peripheral equipment for teaching in polytechnics in North East Zone of Nigeria.

\section{Hypothesis 1}


There is no significant difference in the mean responses of lecturers of College of Engineering Technology, College of Science and Technology and College of Administrative and Business Studies on the ICT competency needs of lecturers in the use of peripheral equipment for teaching in polytechnics in North-East Zone of Nigeria

Data that tested this hypothesis are presented in Table 3.

Table 3: Analysis of Variance (ANOVA) Test for Comparing the Mean Ratings of Responses of the Respondents in College of Engineering Technology, College of Science and Technology and College of Administrative and Business Studies on the ICT Competency Needs of Lecturers in the use of Peripheral Equipment for Teaching in Polytechnics in North-East Zone of Nigeria

\begin{tabular}{llllllll}
\hline $\begin{array}{l}\text { Sources of } \\
\text { Variation }\end{array}$ & df & SS & MS & F-cal & F-crit & Significance & Decision \\
\hline $\begin{array}{l}\text { Between } \\
\text { Groups } 2\end{array}$ & 0.2028 & 0.1014 & & & & \\
Within & & & & 3.45 & 0.054 & S & \\
Groups & 18 & 0.5299 & 0.0294 & & & & \\
\hline TOTAL & 20 & 0.7327 & & & &
\end{tabular}

The data presented in Table 3 tested the hypothesis at degree of freedom (df) 2 and 18 and at 0.05 level of significance. The F-cal value of 3.45 is greater that F-crit value of 0.054 . The result shows that there is a significant difference in the mean ratings of the responses of lecturers of College of Engineering Technology, College of Science and Technology and College of Administrative and Business Studies on the ICT competency needs of lecturers in the use of peripheral equipment for teaching in polytechnics in the North-East Zone of Nigeria. Therefore, the null hypothesiswas rejected and the alternative hypothesis upheld. A Scheffe multiple comparison test was carried out to determine which respondent category is responsible for creating the significant difference. The result is presented in Table 4.

Table 4:Scheffe's Pair-wise Comparison Test on the Mean Ratings of the Responses of the Respondents in College of Engineering Technology, College of Science and Technology and College of Administrative and Business Studies on the ICT Competency Needs of Lecturers in the use of Peripheral Equipment for Teaching in Polytechnics in North-East Zone of Nigeria

\begin{tabular}{lcccc}
\hline \multicolumn{1}{c}{ Pairing type } & Df & Fs & F prime $\left(\mathrm{F}^{\prime}\right)$ & Result \\
\hline CET vs CST & 2 & 3.17 & 0.11 & $\mathrm{Fs}_{1}>\mathrm{F}^{\prime}$ \\
CET vs CABS & 2 & 0.38 & 0.11 & $\mathrm{Fs}_{2}>\mathrm{F}^{\prime}$ \\
CST vs CABS & 2 & 1.35 & 0.11 & $\mathrm{Fs}_{3}>\mathrm{F}^{\prime}$ \\
\hline
\end{tabular}

The data of Table 4 provide the result of the Scheffe multiple comparison test. From the table it can be seen that the Scheffe results for the three comparisons are greater than the F-prime $\left(\mathrm{F}^{\prime}\right)$ in each case. This shows that all the three respondent categories contributed to bringing about the significant difference in the mean scores of the respondents.

\section{FINDINGS OF THE STUDY}

From the foregoing analysis, the results have revealed the following findings:

1. In order for lecturers in the College of Engineering Technology, College of Science and Technology and College of Administrative and Business Studies to teach in the polytechnics in the North-East Zone, the following ICT 
competencies regarding the use of peripheral equipment are needed: Use of the digital camera, use of the web camera for internet communication, use of the scanner to copy messages, setting up and using Liquid Crystal Displays (LCDs) and use of a multimedia projector.

2. There was a significant difference in the mean scores of the responses of lecturers of College of Engineering Technology, College of Science and Technology and College of Administrative and Business Studies on the ICT competency needs of lecturers in the use of peripheral equipment for teaching in polytechnics in the North-East Zone of Nigeria. However, when a Scheffe post-hoc multiple comparison test was conducted, it was found that lecturers in the three Collegeswere responsible for creating the significant difference in the mean scores of the respondents.

\section{DISCUSSION OF FINDINGS}

In order for lecturers in the College of Engineering Technology, College of Science and Technology and College of Administrative and Business Studies to teach in polytechnics in the North-East Zone, the study found that the following ICT competencies regarding the use of peripheral equipment were needed: Use of the digital camera, use of the web camera for internet communication, use of the scanner to copy messages, setting up and using Liquid Crystal Displays (LCDs) and use of a multimedia projector. This finding is in consonance with the work of Miller (1997) which determined the level of usage of 18 selected computer resources by technical teachers. A 4-point scale was used to rate items in the questionnaire, covering the following ICT competency areas, namely, productivity software (word processing, spread sheet, data base management), graphic application (graphics presentation, desktop publishing software), interactive technologies (authority software, multimedia and CD-ROM), telecommunication resources (Internet, electronic mail, commercial on-line services, etc), and Computer Assisted Instruction (Simulation and games, drilling and practice, tutorials, etc). Findings revealed that Business Education Teachers, while utilizing familiar types of computer resources at high levels, were not incorporating the newer technologies in their instruction. The study also found that there were no significant differences within groups in total and categorical use of computers.

The above findings are further buttressed by Idialo (2007) who argued that teachers need to possess the following ICT skills and competencies in order for them to effectively integrate e-learning in the classroom:

1. Operate computers and use basic software for word processing, spreadsheets, e-mail, etc.

2. Evaluate and use computers and related ICT tools for instruction

3. Apply current instructional principles, research and appropriate assignment practices for the use of ICT

4. Evaluate Educational software such as CAD/CAM, arch cad, Corel draw multism and multiband electrical and electronic work bench, and other specific software fitted to their areas of specialization.

5. Create effective computer-based presentation such as using the power point

6. Search the internet for resources

7. Integrate ICT tools into student learning activities across the curriculum

8. Create multimedia documents to support instruction

9. Create hypertext documents to support instruction

10. Demonstrate knowledge of ethics and equity issues related to technology.

11. Keep up-to-date as far as educational technology is concerned.

The finding of the study is further buttressed by Miller (1997) whose work found that Business Education Teachers, while utilizing familiar types of computer resources at high levels, were not incorporating the newer technologies in their instruction such as productivity software (word processing, spread sheet, data base management), graphic application (graphics presentation, desktop publishing software), interactive technologies (authority software, multimedia and CD-ROM), 
telecommunication resources (Internet, electronic mail, commercial on-line services, etc), and Computer Assisted Instruction (Simulation and games, drilling and practice, tutorials, etc), and hence the need for further training.

While the study found that a significant difference existed in the mean scores of the responses of lecturers of College of Engineering Technology, College of Science and Technology and College of Administrative and Business Studies on the ICT competency needs of lecturers in the use of peripheral equipment for teaching in polytechnics in the North-East Zone of Nigeria, Miller's (1997) study found that there were no significant differences within groups in Business Education Teachers in total and categorical use of computers. This finding is however buttressed by Diraso (2000) whose work found did not find significant differences between trained and untrained technical teachers on retraining needs of identified competencies.

\section{CONCLUSION AND RECOMMENDATIONS}

The study examined lecturers' competency needs on the use of peripheral equipment in polytechnics in North-East Zone of Nigeria. Form the findings, the study concluded that College of Engineering Technology, College of Science and Technology and College of Administrative and Business Studies lecturers in polytechnics in the North-East Zone required the following ICT competencies regarding the use of peripheral equipment are needed: Use of the digital camera, use of the web camera for internet communication, use of the scanner to copy messages, setting up and using Liquid Crystal Displays (LCDs) and use of a multimedia projector. The significant difference that existed in the mean scores of the three groups of respondents (Colleges) on the ICT competency needs of the lecturers on the use of peripheral equipment demonstrated how varied and independently the responses were. However, the Scheffe post-hoc multiple comparison test conducted revealed that lecturers in the three College were responsible for creating the significant difference. In view of these findings, the study made the following recommendations:

1. Government needs to increase funding for ICT with a view to upgrading existing ICT facilities and supplying new ones.

2. The international community, especially donor agencies, needs to provide ICT assistance to polytechnics in the NorthEast, most especially in the area of ICT training and facilities supply.

3. There is need for training and retraining of lecturers teaching in polytechnics in the North-East in particular and Nigeria in general.

Generally, teachers are required to have skills and competencies in basic computer operations such as running a word, connection of a computer and its peripherals and moving files between drives A study of this nature has provided useful data on the competency needs of lecturers regarding, especially, the use of peripheral equipment. These data undoubtedly call attention to the need for increased teacher training especially in this age of the computer. Consequently, the recommendations made by the study, if implemented, will go a long way in improving the use of ICT in polytechnics in the North-East Zone

\section{REFERENCES}

Adeyanji, T.K. (2008). Actualizing the Five Year Teacher Education Programme in Nigeria.

Lead Paper, presented at the Annual Conference of the Committee of Deans of Faculties of Education of Nigeria Universities, ABU Zaria.

Amankwah, E. (2011). Relevance of competency-based training in polytechniceducation for national development. Journal of Education and Practice, 2 (6), 49-58.

Amassoma, D. J. Ayanda, D. O. \& Tijani, K. (2010). Internet usage among Nigerian polytechnic students and its impact on manpower development: A case study approach. Journal of Information Technology Impact, 10 (3), 161-170

Anderson, N. \& Baskin, C. (2002). Can we leave it chance? New learning technologies and the problem of professional competence. International Education Journal, 3 (3), 126-137.

Andural, S. I. \&Ikyumen, M. I. (2006). The use of information technology in the teaching/learning of vocational and technical education ion Nigeria. Benue State University Journal of Education, 7, 5359.

Andural, S. I., Aboho, D. A. \&Ikyumen, M. I. (2006). Using information technology to revitalizethe teacher and enhance students' learning towards national development, Benue State University Journal of Education, 7, 99-108

Anderson, J. (1997). Integrating ICT and other technologies in teacher education: Trends, 
issuesand guiding principles. Retrieved on line $7^{\text {th }}$ March 2010, from www.unescobbk.org/fileadmin/user_upload/ict/ebooks/.../4integrating.pdf.

Asabere, N. Y. \& Ahmed, A. M. (2013). Towards enhancing quality in education through information and communication technologies (ICTs) in higher education institutions (HEIs). International Journal of Computer Applications, 62 (8), 10-18.

Ater, L. L., Tiough, D. M. \&Nevka, D. A. (2006). Information technology and challenges of the teacher. Benue State University Journal Of Education, 7, 9-14.

Bennett, J. (2002). The future of computer technology in K-12 education.Phi DeltaKappan, $83(8), 621-626$.

Dahiru, H. M. (2005). Information technology literacy and sustainable development.Nigerian Journal of Science, Technology and Environmental Education, 1, 178-183.

ChindaD.P (2013). Information and communication technology skills retraining needs of Technology Education lecturers for implementation of e-learning in Universities Unpublished Ph.D Thesis, Federal University of Technology, Yola.

Common Wealth Department of Education, Science and Training (2002). Raising the standards: A proposal for the development of an ICT competency framework for teachers (Online). Retrieved February 12, 2011, from http://www.dest.gov.au/NR/rdonlyres/B35D8670-5447-4DFC-8388-IC81F3329113/...

Department of Public Instruction (2002).Basic technology competencies for educators. Retrieved $20^{\text {th }}$ October 2009, from http://www.dpi.state.nc.us/tap/basic.htm.

Diraso, D.K. (2000). Competency needs of technical teachers in Adamawa State. Nigerian Journal of Education and Technology, 1(1), 25-31.

Earle, R.S. (2002). The integration of instructional technology into public education: Promises and challenges. ET Magazine, 42(1), 5-13.

Eraut, M. (1998).Concept of competence.Journal of Inter-Professional Care, 12 (2), 127-139.

Espasa, C. Guasch, T. \& Alvarez, I. (2009). Methodological approach to identifyteachers' ICT competencies in online learning environments in higher education. $13^{\text {th }}$ Biennial Conference, Earli 2009.

Ezeoba, K.O\& Okafor, V.E. (2015). Implementation of e-learning for character andskill development in Nigerian Colleges of Education. International Journal of Advanced Multidisciplinary Research Reports, 1(1), 1-6.

Federal Republic of Nigeria, FRN (2013).National policy on education $6^{\text {th }}$ Edition. Lagos: NERDC Press.

ICT in Education (2004). Information and communication technologies in teacher education: A planning guide.Available at http://www.unescobkk.org/indexphp?ld=3806.

Idialo, E,E, (2007). Quality assurance in teaching and examination of vocational technical education in Nigeria. College Student Journal, 3(4), 33-36.

Issa, A. O (n.d.). Reaching the goals of world summit o information society (WSIS)through effective library and information services provision in Nigeria. Dept. of Library and Information Science, Federal Polytechnic, Offa.

Jegede, P. O. (2009). Assessment of Nigerian teacher educators' ICT training.Issues in Informing Science and Information Technology, 6, 415-420.

Kirschner, P. \&Woperies, I. G. J. H. (2003). Pedagogic benchmarks for information and communication technology in teacher education. Technology Pedagogy and Education, 12 (1), 127-149.

Kozma, R., McGhee, R. Quellmalz, E. \&Zalles, D. (2004). Closing the digital divide: Evaluation of the Worlds Links Program.International Journal of Educational Development, 25(4), 361-381.

Kumar, P. \& Kumar, A. (2003). Effect of web-based project on pre-service and in-service teachers' attitudes towards computers and technology skills. Journal of Computing in Teacher Education, 19 (3), 87-92.

Lelitiren, D. (1997). Factors influencing the success of computer skills learning among inservice teachers. Journal of Educational Technology, 28, 139-141.

Mac-Ikemenjima, D. (2005). e-Education in Nigeria: Challenges and prospects. Paper presented at the $8^{\text {th }}$ UN ICT Task Force Meeting, Dublin, Ireland, from 13-15 April 2005.

Marija, B. \& Palmira, P. (2007). Would-be-teachers' competence in applying ICT: Exposition and preconditions for development. Informatics in Education - An International Journal, 6 (2), 397-410.

Mayisela, T. (2014). Assessing how e-learning implementation has enhanced thelecturers' teaching practices at s South African university. International Journal of Education Science, 6(1), 117-124.

Miller, L.W. (1997). Computer integration by vocation teacher educators.Journal of Vocationaland Technology Education. Retrieved $9^{\text {th }}$ December 2008, from http://www.JVTE/v14nl.

Ojowu, J. O. \&Agbo, G. L. (2006).information technology and distance learning in national development. Benue State University Journal of Education, 7, 73-80.

Peraton, H. \& Creed, C. (2001). Applying new technologies and cost effective delivery system in basic education. Retrieved $2^{\text {nd }}$ October 2008, from http://www.unescodoc.Unesco.org/images..

Tinio, V.L. (2008). ICT in education.UNDP-APDIP, Kuala Lumpur, Malaysia. Retrieved $15^{\text {th }}$ October 2009, from http://www/eprimers.org. 
UNESCO (2002).Report: Teacher education programme through distance learning.

Technology-Curriculum-Cost-Evaluation.Available online at http://www, unesco.org.teachereducation/dlearning.html.

UNESCO (2008a). ICT competency standards for teachers: Policy framework United Kingdom:UNESCO publication.

UNESCO (2008b). ICT competency standards for teachers: Implementation guidelines version 1.0: United Kingdom: UNESCO publication.

Wuru, M.M. (2008). Teaching of Computer Science as a prerequisite fro learning in the current education reforms. Nigeria Journal of Professional Teachers, 1(5), 65-77.

Yakubu, N. A. (2002). The state of polytechnic education in Nigeria.Polytechnic Sector News, $12(22)$

Yusuf, M. O. (2005). An investigation into teachers' self-efficacy in implementing computer education in Nigerian secondary schools. Meridian: A Middle School Computer Technologies Journal, 8 (2), $123-143$.

Yusuf, M. O. \&Balogun, M. R. (2011). Student-teachers' competence and attitudes towards Information and Communication Technology: a case study in a Nigerian university. Contemporary Educational Technology, 2 (1), 18-36. 